\title{
KEMAMPUAN KOGNITIF PESERTA LATSAR CPNS DALAM PENCAPAIAN KINERJA PEGAWAI
}

\author{
Suharno \\ Badan Kepegawaian dan Pengembangan Sumber Daya Manusia Kabupaten Sragen \\ suharnoahmadhasan@gmail.com
}

Diterima: Juli 2020; Disetujui: Oktober 2020

\begin{abstract}
This study aims to determine the effect of Cognitive Ability of CPNS Latsar participants on Employee Performance in the Sragen Regency Government. The object of this research is the CPNS Alumni Latsar 2019 as long as they carry out their duties during a probationary period at the agency where they work. This type of research is a survey research conducted on 66 employees. Sources of research data are employees (alumni of Latsar CPNS), the Organizing Committee, and employee superiors. Data were collected using interview techniques, observation, document study, and questionnaires. Data processing was carried out quantitatively and data analysis using simple linear regression using SPSS 17. The results of data analysis were discussed based on expert opinion and the results of previous studies were used to conclude the research results. Based on the results of the study it can be concluded that the Cognitive Ability of CPNS Participants has a very weak effect on employee performance, the value of the influence of Cognitive Ability on Employee Performance is 0.071. While the magnitude of the influence (R2) of Cognitive Ability on Employee Performance is 0.005; it means that Cognitive Ability affects Employee Performance only by 5\%, while $95 \%$ is influenced by other factors not examined in this study. It is obtained that the number Constant (a) is 64.858 and the Number $Y(b)$ is 1.279; so the regression equation is $64.858+1.279 \mathrm{X}$, meaning that if there is no cognitive ability value, the performance value is 64.858. With a regression coefficient of 1.279 , it means that every addition of 1 cognitive ability value will add a performance value of 1.279. The implication of the results of this study is that efforts to sharpen learning in material that support the Strengthening of Technical Competence in the Field of Duty are needed, because this material is related to the job duties of employees.
\end{abstract}

Keywords: cognitive abilities, CPNS background, employee performance

Abstraksi. Penelitian ini bertjuan untuk mengetahui pengaruh Kemampuan Kognitif peserta Latsar CPNS terhadap Kinerja Pegawai di Pemerintah Kabupaten Sragen. Obyek penelitian ini adalah Alumni Latsar CPNS Tahun 2019 selama mereka melaksanakan tugas jabatannya dalam masa percobaan di instansi tempat tugas mereka. Jenis penelitian adalah penelitian survey yang dilakukan pada 66 orang pegawai. Sumber data penelitian adalah pegawai (alumni Latsar CPNS), Panitia Penyelenggara, dan atasan pegawai. Pengambilan data dilakukan menggunakan teknik wawancara, observasi, studi dokumen, dan kuesioner. Pengolahan data dilaksanakan secara kuantitatif dan analisa data secara regresi linier sederhana menggunakan SPSS 17. Hasil analisis data dilakukan pembahasan berdasarkan pendapat para pakar dan hasil penelitian terdahulu digunakan untuk menyimpulkan hasil penelitian. Berdasarkan hasil penelitian dapat disimpulkan bahwa Kemampuan Kognitif Peserta Latsar CPNS berpengaruh sangat lemah terhadap kinerja pegawai, besarnya nilai pengaruh Kemampuan Kognitif terhadap Kinerja Pegawai sebesar 0,071. Sedangkan besarnya pengaruh $\left(R^{2}\right)$ Kemampuan Kognitif kepada Kinerja Pegawai sebesar 0,005; artinya bahwa Kemampuan Kognitif mempengaruhi Kinerja Pegawai hanya sebesar 5\%, sedangkan yang 95\% dipegaruhi oleh factor lain yang tidak 
diteliti pda penelitian ini. Diperoleh angka Constant (a) sebesar 64,858 dan Angka $Y(b)$ sebesar 1,279; sehingga persamaan regresinya adalah $64,858+1,279 \mathrm{X}$, artinya jika tidak ada nilai kemampuan kognitif maka nilai kinerja sebesar 64,858. Dengan koefisien regresi 1,279 artinya setiap penambahan 1 nilai kemampuan kognitif akan menambahkan nilai kinerja sebesar 1,279. Implikasi dari hasil penelitian ini adalah diperlukan upaya penajaman pembelajaran pada materi yang mendukung Penguatan Kompetensi Teknis Bidang Tugas, karena materi ini berkaitan dengan tugas jabatan pegawai.

Kata kunci: kemampuan kognitif, latsar CPNS, kinerja pegawai

\section{PENDAHULUAN}

Pegawai merupakan sumber daya yang paling penting dalam organisasi pemerintahan. Posisi pegawai sebagai asset yang harus diberikan perhatian karena memiliki peran yang besar dalam mewujudkan pelayanan pemerintahan yang baik. Pegawai Negeri Sipil (PNS) dalam Undang-Undang Aparatur Sipil Negara (UUASN) Pasal 11 memiliki tugas melaksanakan kebijakan publik yang dibuat oleh Pejabat Pembina Kepegawaian sesuai dengan ketentuan peraturan perundang-undangan; dan memberikan pelayanan publik yang profesional dan berkualitas.

Menurut Ombudsman RI bahwa tingkat kepatuhan pemerintah dalam memenuhi standar pelayanan publik masih rendah, kondisi ini tidak hanya terjadi di level pemerintah pusat, juga pemerintah daerah (Taher, 2016). Berkaitan dengan kinerja pegawai dalam pelayanan public oleh pemerintah, penelitian yang dilakukan oleh Sukowati (2010), disimpulkan bahwa rendahnya kinerja organisasi Kantor Kecamatan Kedawung Kabupaten Sragen yang ditunjukkan dengan masih kurang sesuainya kualitas pelayanan dibandingkan dengan harapan masyarakat antara lain disebabkan oleh tingkat pemahaman pegawai terhadap tugas dan fungsi jabatan. Dalam konteks pelatihan Calon Pegawai Negeri Sipil, Peraturan Lembaga
Administrasi Negara Nomor 12 Tahun 2018 tentang Pelatihan Dasar Calon Pegawai Negeri Sipil (Latsar CPNS) menyebutkan bahwa tujuan Latsar CPNS adalah untuk mengembangkan kompetensi CPNS yang diukur berdasarkan kemampuan untuk : menunjukkan sikap perilaku bela negara; mengaktualisasikan nilai-nilai dasar PNS dalam pelaksanaan tugas jabatannya; mengaktualisasikan kedudukan dan peran PNS dalam kerangka Negara Kesatuan Republik Indonesia; dan menunjukkan penguasaan Kompetensi Teknis yang dibutuhkan sesuai dengan bidang tugas.

Penelitian tentang pengaruh pelatihan terhadap kinerja pegawai telah banyak dilakukan, pada umumnya pelatihan mempengaruhi secara signifikan dan positif terhadap kinerja pegawai. Diantaranya penelitian Julianry dkk. (2017) menunjukkan bahwa pelatihan secara signifikan berpengaruh positif terhadap kinerja karyawan akan tetapi berpengaruh negative terhadap kinerja organisasi. Variabel motivasi berpengaruh negative terhadap kinerja karyawan akan tetapi berpengaruh positif terhadap kinerja organisasi, Sedangkan untuk variabel pelatihan berpengaruh positif terhadap motivasi serta kinerja karyawan juga signifikan berpengaruh terhadap kinerja organisasi secara keseluruhan. Penelitian Rakasiwi dkk. (2019) menunjukkan bahwa hasil penelitian yang didapat adalah 
pelatihan berpengaruh signifikan positif terhadap kinerja pegawai. Penelitian Safitri (2019) menyimpulkan bahwa ada pengaruh pelatihan terhadap kinerja karyawan PT. Batam. Penelitian Hanifah (2016, h.19) menyimpulkan bahwa kemampuan kreativitas siswa dapat tercapai jika proses sebelumnya yaitu kemampuan kognitif (mengingat, memahami, dan menerapkan) sudah dikuasai. Kemampuan kognitif menjadi hal yang mendasar bagi kemampuan lain.

Dalam hal penelitian pengaruh Kemampuan Kognitif Peserta Latsar CPNS terhadap Kinerja masih sangat terbatas. Penelitian tentang Latsar CPNS yang dilakukan oleh Subekan A. dan Azwar Iskandar (2019, h. 91) tentang Pengaruh Pemahaman Nilai Dasar 'Aneka' Terhadap Pembentukan Sikap Peserta Latsar CPNS pada Balai Diklat Keuangan Malang menyimpulkan bahwa pemahaman materi nilai dasar (akuntabilitas, nasionalisme, etika publik, komitmen mutu, dan anti korupsi) secara simultan memiliki pengaruh yang positif dan signifikan terhadap pembentukan sikap peserta Latsar. Penelitian Raharjo tentang Efektivitas Diklat Prajabatan Pola Baru Bagi Calon Pegawai Negeri Sipil Kementerian Keuangan menyimpulkan bahwa diklat melalui pemahaman materi-materinya (nilai akuntabilitas, etika publik, komitmen mutu, dan anti korupsi ) memiliki efek positif pada kinerja pegawai; sebaliknya, nilai nasionalisme berpengaruh negatif terhadap kinerja pegawai. Peneliatian Suharto (2019) menunjukkan bahwa hasil belajar mempunyai pengaruh yang positif dan signifikan serta memberikan kontribusi sebesar 28,7\% terhadap komitmen kerja.

Pelatihan Dasar Calon Pegawai Negeri Sipil (Latsar CPNS) adalah pelatihan yang diberikan kepada CPNS sebelum mereka menduduki jabatannya secara penuh. Latsar CPNS bertujuan untuk Pembentukan Karakter PNS dengan cara menanamkan nilai-nilai dasar PNS yang meliputi : akuntabilitas, nasionalisme, etika public, komitmen mutu, dan anti korupsi; dan Penguatan Kompetensi Teknis Bidang Tugas yang meliputi : Kompetensi teknis Umum/Administratif, dan Kompetensi Teknis Substantif. Pembentukan Karakter dilaksanakan melalui pembelajaran secara klasikal untuk memberikan pengetahuan (kemampuan kognitif) dan penanaman sikap perilaku (kemampuan afektif), sedangkan untuk mengimplementasikan karakter dilaksanakan melalui kegiatan Aktualisasi Nilai-Nilai Dasar PNS di instansi tempat mereka ditugaskan atau magang diluar instansi sebagai jabatan teknis administrasi atau teknis substansi (kemampuan psikomotorik).

Penelitian ini bertujuan untuk mengetahui pengaruh pemahaman materi (Kemampuan Kognitif) peserta Latsar CPNS terhadap kinerja dalam melaksanakan pekerjaan sesuai dengan jabatan yang ditugaskan kepadanya (sebagai PNS). Memperhatikan tujuan Latsar CPNS sesuai Peraturan Lembaga Administrasi Negara Nomor 12 Tahun 2018 yang salah satunya adalah Peserta Mampu Menunjukkan Penguasaan Kompetensi Teknis yang dibutuhkan sesuai dengan bidang tugas, maka akan diteliti pengaruh kemampuan kognitif terhadap kinerja pegawai. Berdasarkan tujuan penelitian tersebut diatas, maka rumusan masalah penelitian ini adalah 1) apakah terdapat pengaruh kemampuan kognitf peserta Latsar CPNS terhadap kinerja, dan 2) bagaimana pengaruh kemampuan kognitif peserta pelatihan terhadap kinerja. Berdasarkan uraian diatas, penulis melaksanakan penelitian dengan judul 
"Kemampuan Kognitif Peserta Latsar CPNS dalam Pencapaian Kinerja".

Berdasarkan pada tujuan penelitian dan rumusan masalah, maka hipotesis penelitian ini adalah "Kemampuan Kognitif Peserta Latsar CPNS berpengaruh kepada kinerja pegawai". Disamping itu, kreativitas pegawai dalam melaksanakan tugasnya akan lebih baik karena kemampuan kognitif menjadi hal yang mendasar bagi kemampuan lain.

\section{METODE PENELITIAN}

Jenis penelitian yang dilaksanakan adalah penelitian survey, menurut Zikmund (1997) "metode penelitian survey adalah satu bentuk teknik penelitian di mana informasi dikumpulkan dari sejumlah sampel berupa orang, melalui pertanyaanpertanyaan". Penelitian ini bersifat deskriptif kuantitatif, tujuannya untuk mengetahui dan menjelaskan pengaruh variabel bebas terhadap variabel terikat.

Subyek penelitian adalah alumni Latsar CPNS Golongan II Tahun 2019 Pemerintah Kabupaten Sragen sebanyak 66 orang dengan jabatan dan rincian sebagai berikut.

Tabel 1.

Tugas Jabatan Pegawai

\begin{tabular}{llc}
\hline No & \multicolumn{1}{c}{ Jabatan } & Jumlah \\
\hline 1. & $\begin{array}{l}\text { Tenaga Kesehatan (perawat, } \\
\text { sanitarian, nutrisionis, perekam } \\
\text { medis, terapi wicara, akupasi } \\
\text { terapi) }\end{array}$ & 51 \\
2. & $\begin{array}{l}\text { Teknik Jalan Jembatan, } \\
\text { Pengairan, dan Perumahan }\end{array}$ & 10 \\
3. & Administrasi Kearsipan dan & 5 \\
& Pengelola Kepegawaian & orang \\
\multicolumn{2}{c}{ Jumlah } & 66 \\
\hline Sumber: Dokumen Penyelenggaraan Latsar CPNS & Pemkab Sragen 2019
\end{tabular}

Dalam penelitian ini variable pertama adalah nilai ujian akademik peserta Latsar CPNS (Kemampuan Kognitif). Seperti pada umumnya, pelatihan merupakan proses membekali pengetahuan (kognitif), sikap (afektif), dan ketrampilan (psikomotor) kepada peserta pelatihan agar mereka dapat bekerja lebih baik dalam tugas dan jabatan yang diberikan kepadanya. Menurut Bloom dalam Darmawan dan Edy Sujoko (2013, h. 31) Ranah Kognitif, berisi perilaku-perilaku yang menekankan aspek intelektual (pengetahuan, pengertian, dan keterampilan berpikir); ranah afektif, berisi perilaku-perilaku yang menekankan aspek perasaan dan emosi, seperti minat, sikap, apresiasi, dan kemampuan beradaptasi; sedangkan ranah psikomotor, berisi perilaku-perilaku yang menekankan aspek kemampuan melakukan kegiatan yang bersifat fisik seperti menulis secara langsung dengan tangan, menulis dengan 
mengetik, berolah raga, dan bekerja melayani mesin.

Variabel kedua adalah Kinerja pegawai yang dinilai dengan menggunakan kuesioner yang telah digunakan dalam penelitian Evita dkk (2015) tentang Penilaian Kinerja Karyawan dengan menggunakan Metode Behaviorally Anchore Rating Scale dan Management by Objectives. Pada instrument tersebut terdapat 13 aspek/komponen penilaian kinerja pegawai yaitu : Disiplin, Tanggung jawab, Teamwork, Planning Skills, Leadership, Problem Solving and Decision Taking Skills, Kepatuhan, Kejujuran, Inisiatif, Self-Motivation, Analythical Thinking, Achievement Orientation, dan Inovatif. Setiap aspek dilengkapi rubrik indicator capaian kinerja dengan skor pencapaian antara 1 (skala terendah) sampai dengan 5 (skala tertinggi).

Data penelitian dikumpulkan dari berbagai sumber, yaitu: dokumen dan penyelenggaraan Latsar CPNS Tahun 2019 Kabupaten Sragen, hasil wawancara dengan pejabat, dan penilaian secara langsung kepada para alumni Latsar CPNS Tahun 2019 oleh atasannya. Teknik pengumpulan data dilaksanakan dengan cara : observasi, studi dokumen, wawancara, dan penyebaran kuesioner. Teknik observasi dilakukan untuk melihat dari dekat penyelenggaraan pelatihan, studi dokumen digunakan untuk mendapatkan data tentang kemampuan kognitif peserta dan jabatan di instansinya serta data instansi penyelenggara pelatihan, wawancara dilakukan untuk mendapatkan data dan penjelasannya, sedangkan kuesioner digunakan untuk mendapatkan data tentang kinerja pegawai (alumni Latsar CPNS). Data yang diperoleh kemudian dikumpulkan, ditabulasikan, diolah, dan dianalisis. Pengolahan dan analisis data yang digunakan dalam penelitian ini adalah teknik analisis data kuantitatif regresi linier sederhana menggunakan Aplikasi SPPS 17 for Windows. Dalam analisis data ada tiga komponen yang penting : reduksi data, sajian data, dan penarikan kesimpulan (Sutopo, 1987). Reduksi data merupakan proses pemilihan, pemusatan perhatian pada penyederhanaan data, membuang hal-hal yang tidak penting dan mentransformasikan data-data kasar yang muncul di lapangan. Penyajian data dilakukan secara sederhana melalui tabel dan narasi agar memudahkan dalam pengolahan dan analisis. Penarikan kesimpulan dilaksanakan setelah data dilakukan pengolahan dan analisis secara statistik dengan mendasarkan pada pendapat para ahli maupun hasil penelitian terdahulu. Kesimpulan yang dipaparkan merupakan jawaban dari tujuan penelitian yang sudah ditentukan mendasarkan hipotesis yang dibuat di awal penelitian ini.

\section{HASIL DAN PEMBAHASAN}

\section{Hasil Penelitian}

\section{a. Kemampuan Kognitif}

Kemampuan kognitif peserta pelatihan diperoleh dari nilai ujian materi mata pelatihan yang meliputi mata pelatihan : Akuntabilitas, Nasionalisme, Etika Publik, Komitmen Mutu, dan Anti Korupsi yang pelaksanaan ujiannya dilakukan dalam satu paket soal. Paket soal terdiri dari 100 nomor soal model pilihan ganda dengan 4 opsi (pilihan jawaban) dengan durasi waktu 1 jam (60 menit).

Rekap data kemampuan kognitif Peserta pelatihan seperti disajikan pada Tabel 1 berikut ini. 
Tabel 1.

Kemampuan kognitif peserta pelatihan

\begin{tabular}{clc}
\hline No & \multicolumn{2}{c}{ Komponen } \\
\hline 1 & Jumlah (N) & 66 \\
2 & Nilai Rata-rata & 69.92 \\
3 & Nilai Tertinggi & 81.00 \\
4 & Nilai Terendah & 46.00 \\
\hline
\end{tabular}

Sumber : Data diolah peneliti, 2019

Memperhatikan Tabel 1 tersebut diatas (alumni Latsar CPNS) tempat mereka menunjukkan bahwa nilai rata-rata ditugaskan. Hasil penilaian oleh atas kemampuan kognitif peserta pelatihan pegawai dijumlahkan kemudian dirata-rata sebesar 69,92, kemampuan kognitf tertinggi sebagai nilai kinerja pegawai yang 81,00 dan terendah 46,00 . selanjutnya dianalisis dalam pengolahan data penelitian. Dari jumlah 66 pegawai,

\section{b. Kinerja Pegawai}

Data kinerja pegawai diperoleh dari penilaian dengan menggunakan kuesioner yang disebarkan kepada atasan pegawai nilai tertinggi sebesar 4,54 dan nilai terendah 2,92 dengan nilai rata-rata 3,96. Rekap nilai kinerja pegawai disajikan pada tabel berikut.

Tabel 2.

Nilai Kinerja Pegawai

\begin{tabular}{clc}
\hline No & Komponen & Kinerja \\
\hline 1 & Jumlah $(\mathrm{N})$ & 66 \\
2 & Nilai Rata-rata & 3.96 \\
3 & Nilai Tertinggi & 4.54 \\
4 & Nilai Terendah & 2.92 \\
\hline
\end{tabular}

Sumber : Data diolah peneliti, 2019

\section{Pembahasan}

Berdasarkan hasil analisis statistik variable penelitian dapat dijelaskan bahwa besarnya nilai korelasi (hubungan) antara kemampuan kognitif peserta pelatihan dengan kinerja pegawai diperoleh angka sebesar 0,071. Besarnya pengaruh variable bebas terhadap variable terikat $\left(\mathrm{R}^{2}\right)$ sebesar
0,005; artinya bahwa pengaruh variable bebas (kemampuan kognitif peserta pelatihan) terhadap variable terikat (kinerja pegawai) sebesar 5\%, sedangkan sisanya 95\% dipegaruhi oleh variable lain. Hasil analisis data disajikan pada Tabel 3. berikut ini: 
Tabel 3.

Model Summary

\begin{tabular}{lrrrr}
\hline Model & $\mathrm{R}$ & R Square & $\begin{array}{c}\text { Adjusted R } \\
\text { Square }\end{array}$ & $\begin{array}{l}\text { Std. Error of } \\
\text { the Estimate }\end{array}$ \\
\hline 1 & $.071^{\mathrm{a}}$ & .005 & -.010 & 6.94952 \\
\hline
\end{tabular}

a. Predictors: (Constant), Y

Sumber: Hasil Olah Data

Berdasarkan Tabel 3 diatas dapat kinerja pegawai (Widiyanto, 2010, h. 102). dijelaskan bahwa pengaruh nyata Sejalan dengan pendapat Prasetyo (2019, h. (signifikan) kemampuan kognitif peserta 266-267) bahwa kinerja karyawan secara pelatihan terhadap kinerja pegawai tidak langsung dipengaruhi oleh beberapa ditunjukkan oleh besarnya angka $\mathrm{F}$ factor antara lain : pelatihan, budaya kerja (hitung), yaitu sebesar 0,325 dengan organisasi, lingkungan kerja, dan kepuasan signifikan probabilitas sebesar 0,571 kerja.

$(>0,005)$. Hal ini berarti bahwa kemampuan Output hasil analisis data disajikan pada kognitif peserta pelatihan tidak dapat Tabel 4 (Tabel Analisis Anova) sebagai digunakan sebagai alat untuk memprediksi berikut.

Tabel 4.

Analisis Anova

ANOVA $^{b}$

\begin{tabular}{rlrrrrr}
\hline \multicolumn{1}{l}{ Model } & \multicolumn{1}{c}{$\begin{array}{l}\text { Sum of } \\
\text { Squares }\end{array}$} & Df & $\begin{array}{c}\text { Mean } \\
\text { Square }\end{array}$ & \multicolumn{1}{l}{ F } & \multicolumn{1}{c}{ Sig. } \\
\hline 1 & Regression & 15.684 & 1 & 15.684 & .325 & $.571^{\mathrm{a}}$ \\
& Residual & 3090.937 & 64 & 48.296 & & \\
& Total & 3106.621 & 65 & & & \\
\hline
\end{tabular}

a. Predictors: (Constant), Y

b. Dependent Variable: X

Sumber: Hasil Olah Data

Selanjutnya melalui output Coeficients Berikut ini disajikan hasil analisis pada Tabel 5 dapat dijelaskan persamaan persamaan regresi.

regresi atas variabel variabel penelitian. 
Tabel 5.

Output Persamaan Regressi

Coefficients $^{\mathrm{a}}$

\begin{tabular}{lcrrrrr}
\hline \multicolumn{7}{c}{ Unstandardized } \\
Coefficients & \multicolumn{2}{c}{$\begin{array}{c}\text { Standardized } \\
\text { Coefficients }\end{array}$} \\
Model & $\mathrm{B}$ & Std. Error & Beta & \multicolumn{1}{c}{ t } & Sig. \\
\hline 1 (Constant) & 64.858 & 8.931 & & 7.262 & .000 \\
Y & 1.279 & 2.245 & .071 & .570 & .571 \\
\hline
\end{tabular}

a. Dependent Variable: $\mathrm{X}$

Sumber: Hasil Olah Data

Berdasarkan Tabel 5 tersebut diatas diperoleh angka Constant (a) sebesar 64,858 dan Angka Y (b) sebesar 1,279; maka persamaan regresinya adalah : 64,858 $64,858+1,279$ X. Hal ini dapat dimaknai bahwa dengan konstanta sebesar 64,858 menunjukkan bahwa apabila tidak ada nilai kemampuan kognitif, maka nilai kinerja pegawai sebesar 64,858. Sedangkan koefisien regresi sebesar 1,279 memberikan gambaran bahwa setiap penambahan 1 nilai kemampuan kognitif maka akan menambahkan nilai kinerja sebesar 1,279.

Hipotesis penelitian ini adalah $\mathrm{H}_{0}=$ tidak ada pengaruh nyata (signifikan) kemampuan kognitf peserta pelatihan terhadap kinerja, dan $\mathrm{H}_{1}$ = ada pengaruh nyata (signifikan) kemampuan kognitif peserta pelatihan terhadap kinerja. Dari ouput tersebut diperoleh nilai $\mathrm{t}$ hitung sebesar 7,262 dengan probabilitas sebesar 0,571 (> 0,05) maka $\mathrm{H}_{0}$ diterima, artinya bahwa tidak ada pengaruh yang nyata (signifikan) variable kemampuan kognitif peserta pelatihan terhadap kinerja.

Penelitian yang dilakukan oleh Hasan (2019, h.57), menyimpulkan bahwa terdapat factor-faktor didalam organisasi yang mempengaruhi pada kinerja pegawai, seperti : (1) organisasi harus memiliki dokumen analisis jabatan, (2) kesesuaian penempatan PNS dalam suatu jabatan dengan latar belakang pendidikan, pelatihan yang pernah diikuti, dan kompetensi yang dimiliki, (3) rendahanya controlling atasan kepada bawahannya dalam memberikan penilaian prilaku kerja bawahannya, dapat menimbulkan penilaian kinerja yang tidak bersifat objektif dan penghambat dalam penilaian kinerja.

Menurut Suprapti (2013, h.30), dijelaskan bahwa kesuksesan seseorang dalam pekerjaannya tidak semata-mata ditentukan oleh pengetahuan dan kemampuan teknis yang dimilikinya, tetapi kesuksesan seseorang ditentukan oleh kompetensi yang dimiliki meliputi kemampuan kognitif, ketrampilan dan sikap perilaku. Lebih lanjut dijelaskan bahwa menurut Spencer and Spencer (1993, h.11) dalam Suprapti (3013, h.32) dinyatakan bahwa dalam model teori gunung es sebagai puncaknya adalah pengetahuan dan ketrampilan, maknanya bahwa pengetahuan dan ketrampilan yang dimiliki oleh seseorang bukan satu-satunya factor pendukung keberhasilan seseorang dalam melaksanakan pekerjaan jabatannya.

Menurut Wijayanto (2011, h.87), dalam penelitiannya menyimpulkan bahwa "konsep diri dan lingkungan keluarga, serta sosial dimana individu tumbuh berpengaruh 
terhadap pembentukan mutu diri (karakteristik mendasar) yang terkait dan sulit untuk dipisahkan dengan kompetensi lunak (kemampuan beradaptasi dan berinteraksi). Kompetensi lunak lebih nyata mempengaruhi kinerja dibandingkan dengan kompetensi keras, meskipun keduanya berkontribusi terhadap kinerja karyawan." Selanjutnya dinyatakan bahwa : "dari semua pembentuk kompetensi lunak, komitmen dalam menggapai tujuan hidup seseorang (motivasi) adalah yang paling kuat menentukan tingkat penguasaan kompetensi lunak seseorang yang pada akhirnya berdampak meningkat kinerjanya."

Penelitian yang dilaksanakan oleh Pakpahan (2011, h. 120) di Badan Kepegawaian Daerah Kota Malang mendapatkan kesimpulan bahwa peranan pendidikan terhadap kinerja pegawai cukup baik, sedangkan peranan pelatihan terhadap kinerja pegawai rendah.

Ansori (2015, h. 59) dalam penelitiannya di Kabupaten Bungo menyimpulkan bahwa kinerja pegawai dipengaruhi secara bersama oleh factor kompetensi dan motivasi pegawai, sedangkan kompetensi meliputi pengetahuan dan ketrampilan yang dibutuhkan untuk melaksanakan pekerjaan. Menurut Payaman dalam Djaniar (2019, h. 29) dijelaskan bahwa faktor-faktor yang mempengaruhi kinerja karyawan dapat digolongkan dalam tiga kelompok yaitu (1) menyangkut kualitas dan kemampuan fisik karyawan, (2) sarana pendukung, dan (3) supra sarana. Kualitas dan kemampuan karyawan meliputi tingkat pendidikan, latihan, disiplin, motivasi kerja, etos kerja, status kepegawaian, mental dan kemampuan fisik karyawan yang bersangkutan.

Sejalan dengan pendapat para ahli dan hasil penelitian terdahulu serta hasil analisis statistic pada penelitian ini menunjukkan bahwa kemampuan kognitif peserta pelatihan dasar CPNS Kabupaten Sragen Tahun 2019 belum dapat memberikan gambaran pengaruhnya terhadap kinerja pegawai. Hal ini berarti bahwa masih terdapat banyak komponen lainnya yang tidak menjadi variable pada penelitian ini tetapi menjadi komponen kompetensi yang seharusnya dimiliki seseorang dalam mencapai kesuksesan kinerjanya. Komponen kompetensi tersebut meliputi : pengetahuan, ketrampilan, sikap dan perilaku, kemampuan beradaptasi dan berinteraksi, motivasi, serta lingkungan kerja. Disamping itu bahwa kompetensi lunak mempengaruhi lebih nyata dibandingkan kompetensi keras yang dimiliki oleh pegawai.

\section{SIMPULAN}

Kinerja pegawai sangat mempengaruhi kinerja organisasi, meningkatnya kinerja organisasi berarti bahwa organisasi semakin baik melakukan peran dan fungsinya sesuai dengan visi dan misi yang telah ditetapkan sebagai tujuan utama organisasi. Peningkatan kinerja pegawai di instansi pemerintah dapat ditempuh dengan beberapa cara, antara lain dengan pemberian pendidikan dan pelatihan.

Berdasarkan uraian, analisis data, dan pembahasan dalam penelitian ini dapat disimpulkan bahwa terdapat korelasi antara kemampuan kognitif dengan kinerja pegawai. Derajad korelasi antara kemampuan kognitif peserta pelatihan dasar CPNS Golongan II dengan kinerja adalah sangat lemah.

Pengaruh kemampuan kognitif peserta pelatihan yang diperoleh selama pelatihan kepada kinerja pegawai hanya sebesar 5\%, sedangkan sisanya yang 95\% komponen 
kinerja pegawai dipengaruhi oleh faktor teknis bidang tugas. Keberagaman lain yang tidak dibahas dalam penelitian ini. kompetensi peserta pelatihan sebaiknya Implikasi hasil penelitian ini adalah, oleh dijadikan pertimbangan dalam penyusunan karena kemampuan kognitif berpengaruh kelas agar pembelajaran materi yang sangat lemah terhadap kinerja, maka mendukung kemampuan teknis bidang diperlukan penguatan pada pembelajaran tugas diperoleh hasil yang maksimal.

materi yang mendukung pada kemampuan

\section{DAFTAR PUSTAKA}

Ansori (2015). Analisis Pengaruh Kompetensi dan Promosi Terhadap Kinerja Pegawai Negeri Sipil Pada Sekretariat Daerah Kabupaten Bungo. Jurnal Ilmiah Universitas Batanghari Jambi Vol.15 No.1 Tahun 2015

Darmawan, I.P.A, \& Sujoko, E. (2013). Revisi Taksonomi Pembelajaran Benyamin S. Bloom. Jurnal. Satya Widya, Vol. 29, No.1. Juni 2013: 30-39

Djaniar U., Hasyim, A. M., \& Mustari, V.H., (2019). Faktor-Faktor Yang Mempengaruhi Kinerja Pegawai Negeri Sipil Pada Kantor Balai Pendidikan Dan Pelatihan Kehutanan Kupang. Jurnal Manajemen Volume 3 No. 2 Oktober 2019 ISSN : 23033495 .

Evita, S.N., \& Muizu, W.O.Z., \& Atmojo, R.T., W., (2017). Penilaian Kinerja Karyawan dengan Menggunakan Metode Behaviorally Anchore Rating Scale dan Management by Objectives. Pekbis Jurnal, Vol.9, No. 1, Maret 2017:18-32

Hanifah, D.P.,Marwoto, P., Sugiarto.(2016). Pengaruh Kemampuan Kognitif, Kreativitas, dan Memecahkan Masalah Terhadap Sikap Ilmiah Siswa SD. Journal of Primary Education 5 (1) (2016)

Hariyanto, K., \& Satoto, E.B., (2016). Kriteria Yang Berpengaruh Dalam Penilaian Kinerja Karyawan Menggunakan Anaytical Hierarchy Process. JITI, Vol.15 (1), Jun 2016, $19-26$.

Hidayat, N., (2017). Pengaruh Diklat (Pendidikan dan Pelatihan) Terhadap Prestasi Kerja Karyawan Di Bank BPR Rokan Hulu. Jurnal Ilmiah Cano Ekonomos Vol. 6 No. 1 Januari 2017.

Nurhayati, A.H., (2018). Pendidikan dan Pelatihan Sebagai Upaya Peningkatan Kinerja Pustakawan. LIBRIA, Vol. 10, No. 1, Juni 2018 (95-115).

Prasetyo (2019). Pengaruh Pelatihan, Lingkungan Kerja, dan Budaya Organisasi Terhadap Kinerja Karyawan Dengan Kepuasan Kerja Sebagai Variabel Intervening Di Sekretariat Badan Pelatihan dan Pendidikan Keuangan (BPPK) Jakarta. Skripsi, Universitas Islam Indonesia Fakultas Ekonomi Yogyakarta 2019. Vocational Education and Technology Journal, Vol. 1, No.1, September 2019, hal. 51-56

Rezita, R. (2015). Pengaruh Pendidikan dan Pelatihan (Diklat) terhadap Kinerja Pegawai pada Badan Perpustakaan dan Arsip Daerah Daerah Istimewa Yogyakarta (BPAD DIY). Skripsi. Program Studi Pendidikan Administrasi Perkantoran Jurusan Pendidikan Administrasi Fakultas Ekonomi. Universitas Negeri Yogyakarta.

Saida, S.N., (2019). Upaya Meningkatkan Kinerja Melalui Pendidikan dan Pelatihan Jabatan bagi Pegawai pada Kantor Imigrasi Kelas I TPI Yogyakarta. Program Studi 
Manajemen Perusahaan Program Diploma III Fakultas Ekonomi Universitas Islam Indonesia.

Subekan A., \& Iskandar, A. (2019). Pengaruh Pemahaman Nilai Dasar 'Aneka' Terhadap Pembentukan Sikap Peserta Latsar CPNS pada Balai Diklat Keuangan Malang. Jurnal Pendidikan, Volume 20, Nomor 2, September 2019, 91-110.

Sukowati, K. (2010). Kinerja Organisasi Kantor Kecamatan Kedawung Kabupaten Sragen. Tesis, Program Pasca Sarjana, Universitas Sebelas Maret, Surakarta.

Suprapti, W., \& Irawan, D.A., (2017). Revolusi Soft Skill Memandu Pembelajaran Efektif dengan Metode 7 M. Mojokerto : CV. Sepilar Publishing House.

Triyanto. (2011). Model-model Pembelajaran Inovatif Berorientasi Konstruktivistik Konsep, Landasan Teoritis-Praktis dan Impelementasinya. Jakarta: Prestasi Pustaka.

Triasmoko, D., \& Moch. Djudi Mukzam, M.D., Nurtjahjono, G.E., (2014). Pengaruh Pelatihan Kerja Terhadap Kinerja Karyawan (Penelitian pada Karyawan PT Pos Indonesia (Persero) Cabang Kota Kediri). Jurnal Administrasi Bisnis (JAB)|Vol. 12 No. 1 Juli 2014.

Widiyanto, J. (2010). SPSS For Windows Untuk Analisis Data Statistik dan Penelitian. Surakarta : Kerjasama Laboratorium Komputer FKIP Universitas Muhammadiyah Surakarta dengan BP-FKIP UMS.

Wijayanto, A. (2011). Faktor-faktor yang Mempengaruhi Kompetensi Kerja Karyawan (Determinants for Employee's Work Competencies). Manajemen IKM, September 2011 (81-87) Vol. 6 No. 2 ISSN 2085-8418.

https://www.dosenpendidikan.co.id/taksonomi-bloom/

https://tirto.id/rapor-merah-pelayanan-publik-di-indonesia-b8zr

https://ombudsman.go.id/perwakilan/news/r/pwk--hasil-penilaian-survei-kepatuhan-

standar-pelayanan-publik 